\title{
Effective Utilization of Coal via Flash Pyrolysis
}

\author{
Wei-Chun XU1) and Akira TOMITA2)
}

1) Research \& Development Center, Osaka Gas Co., Ltd., Torishima, Konohana-ku, Osaka, Osaka-fu, 554 Japan.

Research Institute of Non-Aqueous Solutions, Tohoku University, Katahira, Aoba-ku, Sendai, Miyagi-ken, 980 Japan.

2) Chemical

(Received on March 28, 1990; accepted in the final form on May 19, 1990)

\begin{abstract}
Pyrolysis is a fundamental reaction in all coal conversion process: combustion, gasification and liquefaction in addition to coke-making process. Gaseous and liquid products evolved during pyrolysis have been used as fuels and chemical feedstocks. It is important to promote the production of these products for the effective utilization of coal. Attention has been paid to flash pyrolysis of coal for this purpose. In this review, the effects on pyrolysis process are examined. Coal type, carrier gas, pressure, heating rate, final temperature, and residence time in the secondary reactions all affect the product yields. The efforts are made to make clear how to control the product distribution based on the mechanism of coal pyrolysis. The features of coal flash hydropyrolysis processes including those developed and under development are also described.
\end{abstract}

KEY WORDS: coal; flash pyrolysis; hydropyrolysis; pyrolysis products; SNG; tar.

\section{Introduction}

Coal has been used mainly as fuel from ancient time. Even in the modern times, coal still plays an important role as energy source. For instance, power generation and heat production by direct combustion of coal, including pulverized coal combustion and fluidized bed combustion, as well as combustion of gas produced from coal gasification are typical coal utilization methods. Main energy sources have changed from coal to petroleum in the middle of this century. However, the continuation of coal utilization seems to be unavoidable in view of recent energy situation, and thus the economics of coal utilization is an important subject to be considered.

Pyrolysis is a fundamental reaction in all coal conversion processes like combustion, gasification, liquefaction and so on. Especially it is a main reaction in coke-making process. Many studies relating to coke-making have been carried out by slowly heating coal particles in oxygen-free conditions. Coke is obtained by heating coal, and gaseous and liquid products, largely polynuclear aromatic hydrocarbons, are evolved as by-products. These by-products have higher economic value than coal itself and have been used as chemical feedstocks in many industrial fields. Thus it is possible to improve the economic efficiency of coal utilization by promoting the production of these by-products, instead of using all part of coal as energy source. In coke-oven operation, the operation conditions are determined in order to maximize the quality of coke. It is difficult to change them for the purpose of increasing the yields of by-products. From 1960's, flash pyrolysis and flash hydropyrolysis of coal have been carried out, because a high heating rate produces more gaseous and liquid products than a slow heating coking process does.
Flash pyrolysis significantly differs from the traditional coke-making process in many aspects: the purpose, the requirement for feed coal, the heating rate, the kind of carrier gas, and others. Generally speaking, flash pyrolysis can use all types of coal except anthracite to produce SNG (substituted natural gas), chemical feedstocks like BTX (benzene, toluene and xylenes), and other desirable products. The operation conditions can be easily adjusted to the purpose of the process. Furthermore, the liquid-solid separation process is not necessary in contrast to a liquefaction process. Pyrolysis process also possesses a high flexibility in production capacity. Therefore, it would be capable to use coal more effectively and economically.

It became clear from many studies that many factors, for example, coal type, mineral matter in coal, carrier gas, pressure, heating rate, final temperature, and the secondary reactions of primary volatiles, affect the product yields in coal pyrolysis as can be seen in some excellent reviews. ${ }^{1-5)}$

In the present paper, the authors try to make clear how to control the product distribution based on the mechanism of coal pyrolysis. The features of coal flash hydropyrolysis processes including those developed and under development are described. The problems to be solved will be also discussed.

\section{Pyrolysis Scheme of Coal Molecule}

\subsection{Thermal Decomposition of Coal Molecule}

\subsubsection{Formation of Free Radicals}

Coal molecule consists of many kinds of polynuclear aromatic units, which are connected by various bridges like $-\mathrm{CH}_{2}-,-\mathrm{CH}_{2}-\mathrm{CH}_{2-},-\mathrm{CH}_{2}-\mathrm{O}-,-\mathrm{S}-$ and $-\mathrm{O}-$ to form high molecular weight structure (Fig. 1). ${ }^{6)}$ There are also many kinds of oxygen-contain- 

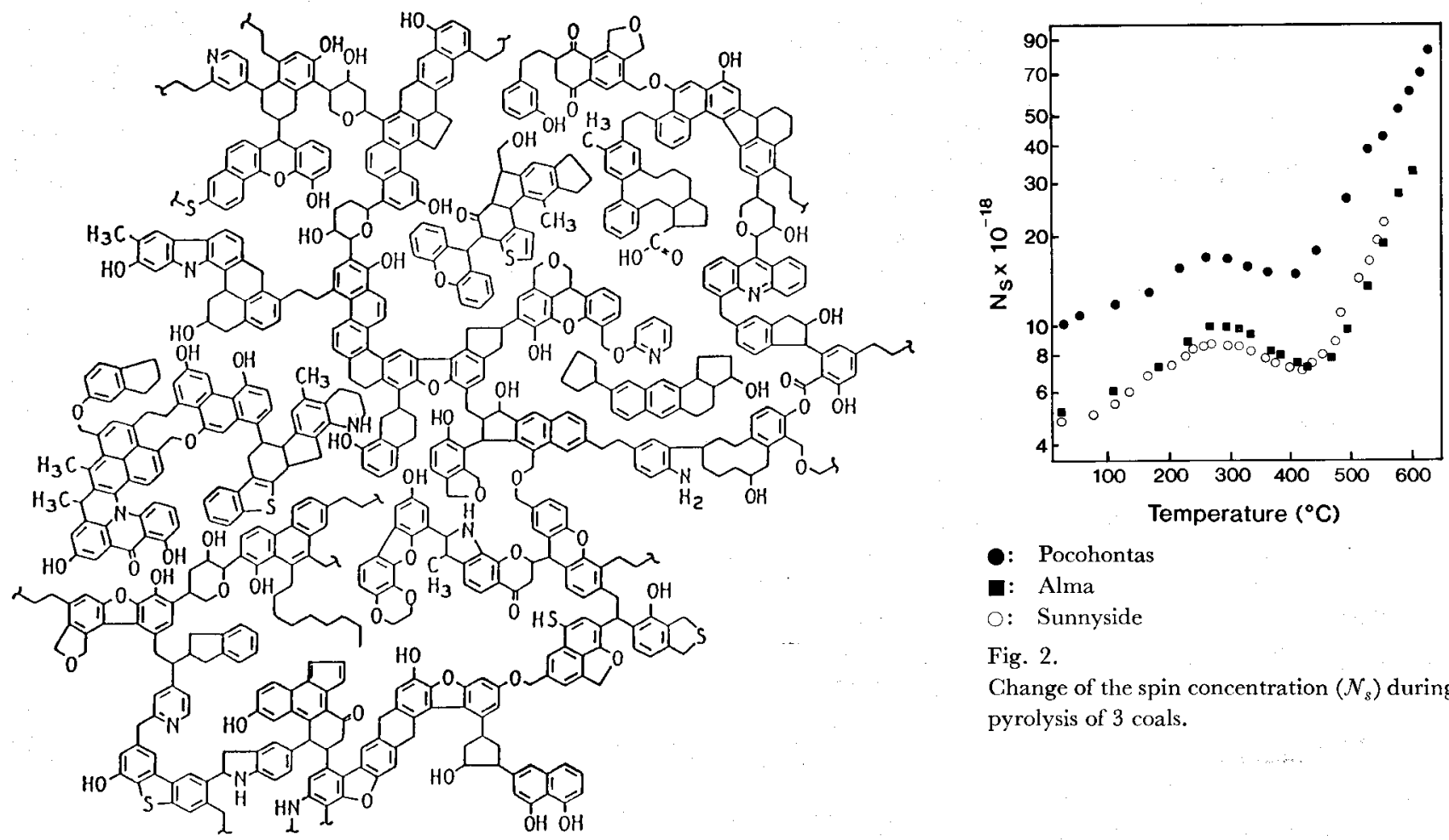

Fig. 2.

Change of the spin concentration $\left(\mathcal{N}_{s}\right)$ during pyrolysis of 3 coals.

Fig. 1. Model of a molecular structure of a bituminous coal.

ing functional groups, like hydroxyl and carboxyl, and hydrocarbon side-chains like methyl and ethyl. The structure of coal molecule differ from one coal to another, according to the coalification conditions. The bond energies of different bridges are different from each other. Even for the same type of bridge, the bond energy varies with the surrounding structures.7) Upon heating, the bridges having lower bond energies would first decompose. It has been experimentally confirmed that a large number of free radicals, which correspond to the spin concentration in ESR measurement, forms from the decomposition of such bridges as shown in Fig. 2.8) The free radicals produced below $250^{\circ} \mathrm{C}$ are less and they are mainly related to the formation of $\mathrm{CO}_{2}$ and $\mathrm{H}_{2} \mathrm{O}$. At higher temperatures, significant decomposition of coal molecule results in the formation of a large number of radicals, but the spin concentration shows a small decrease at around $350^{\circ} \mathrm{C}$ because of quenching of radicals by $\mathrm{H}_{2}$ gases evolved. The temperature dependence of spin concentration is similar for different types of coals.

Many efforts were made to investigate the mechanism of coal pyrolysis. For instance, Solomon and co-workers ${ }^{9,10)}$ found that the temperature of tar formation changes with coal type; the temperature for sub-bituminous and bituminous coals is higher than that for low rank coals. They also studied the formation of tar by pyrolyzing various aromatic polymers as model compounds of coal. Comparison between pyrolysis of coal and model polymers suggests that the decomposition of $-\mathrm{CH}_{2}-\mathrm{CH}_{2}-$ bridges is responsible for the tar formation in the case of high rank coals, while in the case of low rank coals in which a large amount of oxygen-containing functional groups ex- ists, the decomposition of $-\mathrm{CH}_{2}-\mathrm{O}$ - bridges becomes more important for tar formation. Ettinger et al. ${ }^{11}$ studied the pyrolysis of O-ethylphenyl coal, Coal-O$\mathrm{CD}_{2} \mathrm{CD}_{2} \mathrm{C}_{6} \mathrm{H}_{5}$. Upon heating the coal, deuterated toluene and ethylbenzene were evolved, suggesting the decompositions at oxymethylene and dimethylene bridges, followed by stabilization of radicals formed, as in the case of pyrolysis of aromatic polymers mentioned above. Rose et al. ${ }^{12}$ ) showed that larger amounts of deuterated benzene and toluene were obtained from pyrolysis of O-alkylated coal, Coal-O$\mathrm{CD}_{2} \mathrm{C}_{6} \mathrm{D}_{5}$, than from $\mathrm{C}$-alkylated coal, Coal-C$\mathrm{CD}_{2} \mathrm{C}_{6} \mathrm{D}_{5}$. This supports that the oxymethylene bridge is weaker than dimethylene bridge. Lower yield of deuterated benzene than that of deuterated toluene showed that $\mathrm{C}_{\mathrm{ali}}-\mathrm{C}_{\mathrm{ar}}$. bond is rather stronger than $\mathrm{C}_{\mathrm{ali}}$. $\mathrm{C}_{\mathrm{ali}}$. bond.

For the formation of gaseous products, it is generally agreed that hydrocarbon gases come from the decomposition of aliphatic hydrocarbon structures of coal molecule, while inorganic gases $\left(\mathrm{CO}, \mathrm{CO}_{2}\right.$ and $\mathrm{H}_{2} \mathrm{O}$ ) come from the decomposition of oxygen-containing functional groups, and $\mathrm{H}_{2}$ comes mainly from condensation reactions of aromatic nuclei. ${ }^{13,14 \text { ) }}$

\subsubsection{Stabilization of Free Radicals}

The radicals formed from bridge decomposition would be stabilized and finally become pyrolysis products. The stabilization process thus is very important to volatile production.

During pyrolysis in inert carrier gases, recombination of large radicals to each other results in the production of char. On the other hand, the stabilization of relatively small radicals by $\mathrm{H}$ radicals would yield volatile products. Therefore, the yields of vola- 
tiles, including gas and tar, depend strongly on the $\mathrm{H}$ content in coal as shown in Fig. $\left.3 .{ }^{15}\right)(\mathrm{H} / \mathrm{C})_{\text {org. }}$. means the atomic ratio of organic hydrogen to carbon which was calculated by subtracting the contents of $\mathrm{H}$ and $\mathrm{C}$ in inorganic gases from the values of ultimate analysis of coals.

Gaines and Yurum ${ }^{16}$ ) investigated how the $\mathrm{H}$ atoms in coal molecules stabilize radicals. First, they introduced -CHD-CHD- groups by reducing the aromatic structure of raw coal according to the Birch method. Upon pyrolysis, the structure of -CHDdisappeared while aromatic C-D bond became observable. This suggests that the methylene groups are easily dehydrogenated during pyrolysis. $\mathrm{H}$ atoms thus produced can stabilize the radicals effectively.

Rose et al. ${ }^{12)}$ carried out the pyrolysis of deuterated benzylated coal, Coal-O- $\mathrm{CD}_{2} \mathrm{C}_{6} \mathrm{D}_{5}$ and Coal-G$\mathrm{CD}_{2} \mathrm{C}_{6} \mathrm{D}_{5}$. In addition to higher yields of deuterated benzene and toluene, higher yield of deuterated methane, $\mathrm{CH}_{3} \mathrm{D}$, was obtained from pyrolysis of Coal-O$\mathrm{CD}_{2} \mathrm{C}_{6} \mathrm{D}_{5}$ than that from Coal- $\mathrm{C}-\mathrm{CD}_{2} \mathrm{C}_{6} \mathrm{D}_{5}$. The formation of $\mathrm{CH}_{3} \mathrm{D}$ might be the result of stabilization of methyl radicals by introduced deuterium. These results show how important the aliphatic hydrogen in coal molecule is for stabilizing radicals and forming volatiles.

The $\mathrm{H}$ content in coal is not enough for stabilizing the radicals formed, and thus the addition of $\mathrm{H}$ atoms is necessary for increasing the production of volatiles. Comparing the results in inert atmosphere, the production of gas and liquids are promoted in hydrogen atmosphere because of the reactions between coal molecules or primary volatiles and hydrogen gas (Fig. 4).7) Such reactions can be catalyzed by suitable catalysts. For example, the existences of $\mathrm{SnCl}_{2}$ and $\mathrm{ZnCl}_{2}$ increase the conversion of coal to volatiles during coal hydropyrolysis. ${ }^{17)}$

\subsection{Dependence of Product Yields on Temperature and Coal Type}

Effect of coal type on product yields was studied by Ouchi and $H_{0}{ }^{18} a^{18}$ by means of slow heating technique. Recently, the behavior of flash pyrolysis of various types of coals ranging from lignite to anthracite was investigated using Curie-point pyrolyzer in which less secondary reactions of primary volatiles would occur. ${ }^{13)}$ The product yields depend on coal

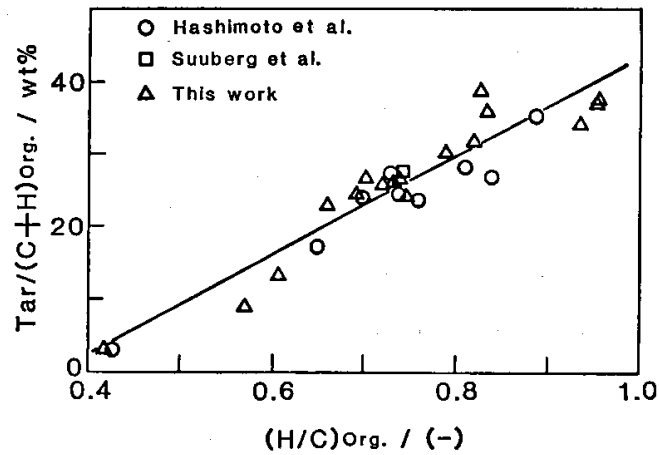

Fig. 3. Relationship between tar yield and the ratio of $(H /$ $C)_{\text {org. }}$ in raw coal. type (Fig. 5); larger amounts of O-containing products are evolved from lignites, whereas higher yields of hydrocarbons are obtained from bituminous coals. Such results reflect the difference in the molecular structure of raw coal.

Effect of pyrolysis temperature on product yields was extensively investigated. The dependence of product yields on temperature are generally different according to the type of reactor used (Fig. 6). ${ }^{19-21)}$ Such difference might be attributed to the secondary reactions of primary volatiles as will be stated later;

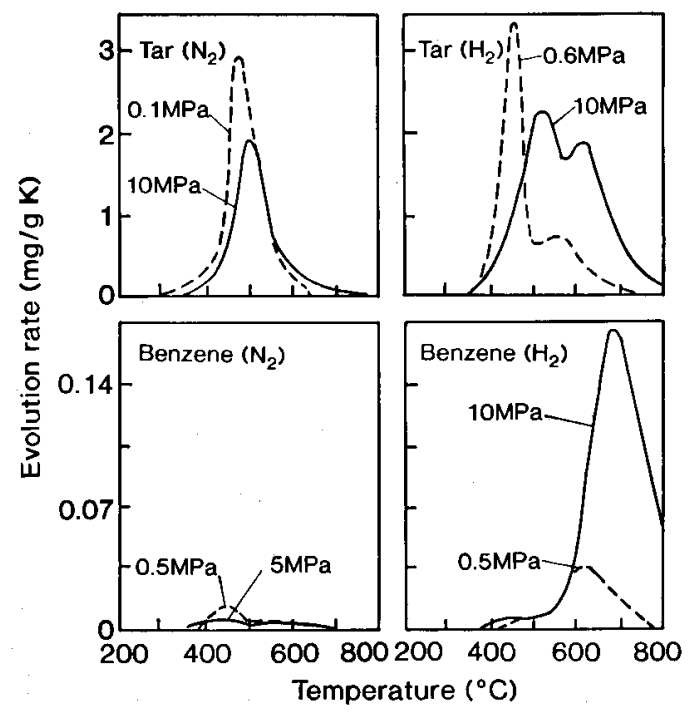

Fig. 4. Effect of carrier gas on the production rate of tar and benzene from pyrolysis of a high-volatile bituminous coal. (Heating rate: $3^{\circ} \mathrm{C} / \mathrm{min}$ )

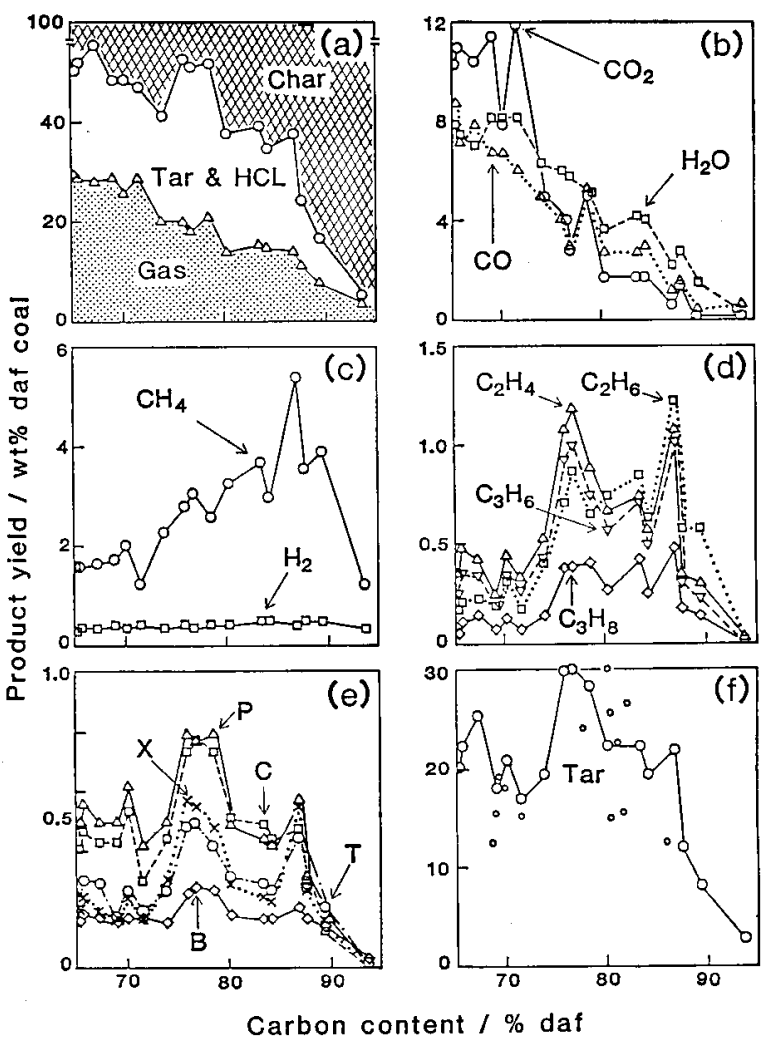

Fig. 5. Effect of coal type on the product yield upon flash pyrolysis. (0.1 $\mathrm{MPa} \mathrm{Ar} ; 764^{\circ} \mathrm{C}$ ) 
the secondary reactions decrease the tar yield. Fig. 7 shows the dependence of the relative yield against pyrolysis temperature; the yields at different temperatures are plotted as relative values to the yield at $764^{\circ} \mathrm{C}$. The data for 7 coals are indicated in the same figure. The temperature dependence for each product depends on the kind of compounds but not on coal type, suggesting that pyrolysis reactions occur in a similar mechanism for all type of coals. ${ }^{21)}$

\subsection{Diffusion of Primary Volatiles through Pores}

The fact that particle size affects the product yields has been recognized in many studies. For instance, Anthony et al. ${ }^{22)}$ showed that the yields of gas and light hydrocarbon liquids increased by $1.4 \%$ and char yield increased by $2.8 \%$, while the yield of tar and other heavy hydrocarbon liquids decreased by $4.6 \%$ when the average particle size increased from 74 to $900 \mu \mathrm{m}$. Similar results were obtained by Roy et al. ${ }^{23)}$

The effect of particle size can be explained as a result of the secondary reactions during diffusion of primary volatiles through pores of coal particles. The larger the particle size, the diffusion is more difficult and thus the condensation and polymerization of primary volatiles would more easily occur. The minerals in particle may promote such reactions. As a result, the yields of tar decreases when increasing particle size. Therefore, for the production of light liquids, the use of small particles would be preferable.

Fig. 8 shows that the yicld of volatiles decreases with the increase in the pressure of non-reactive carrier gas. ${ }^{19,24)}$ As the pressure increases, the primary volatiles stay longer in pores, thus being suffered from
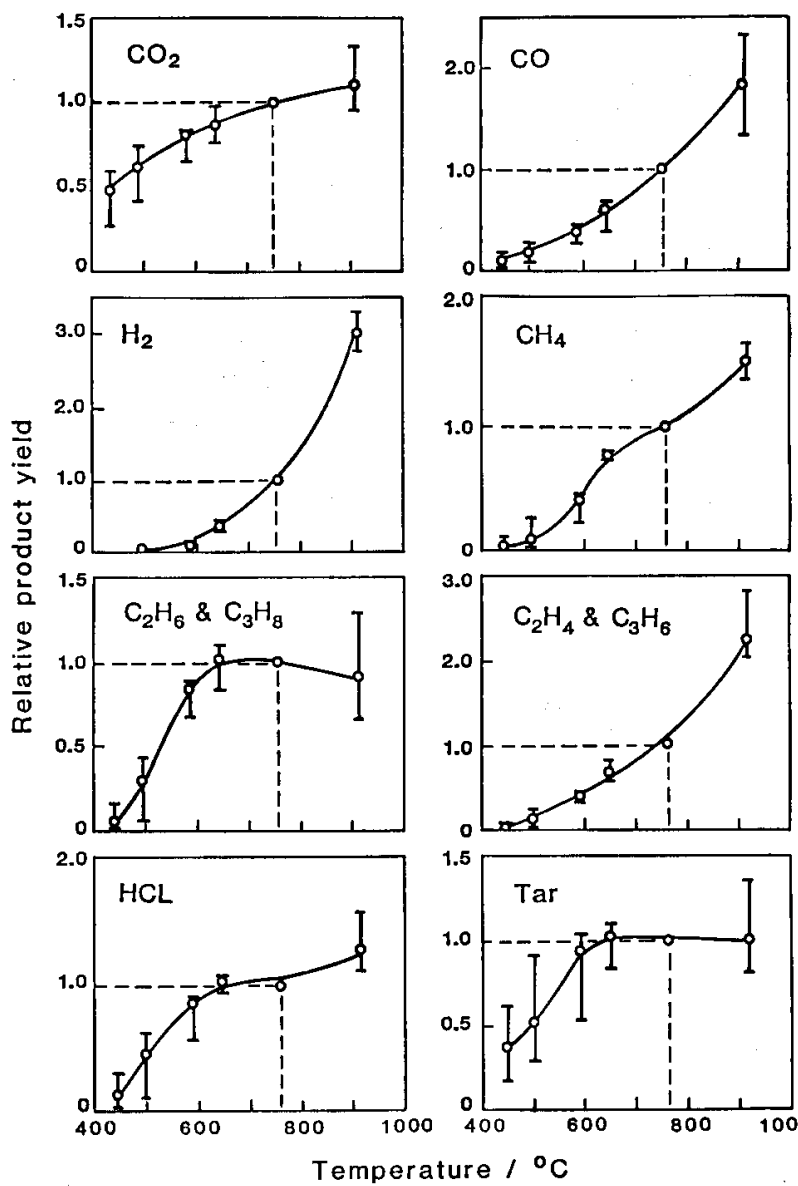

Circles and bars indicate the median and the range of the ratios, respectively.

Fig. 7. Relative yield of various products against the yield at $764^{\circ} \mathrm{C}$ upon flash pyrolysis of 7 coals in Ar.

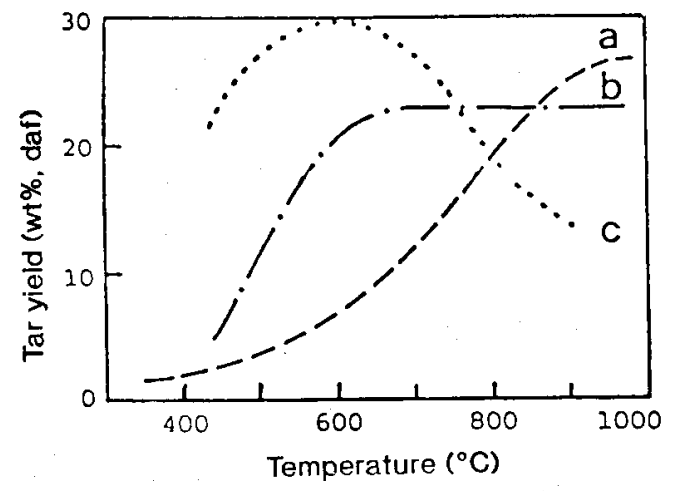

$a$ : Mesh heater (Pittsburgh coal)

$b$ : Curie-point pyrolyser (Liddell coal)

$c$ : Fluidized bed (Liddell coal)

Fig. 6. Temperature dependence of tar yield.

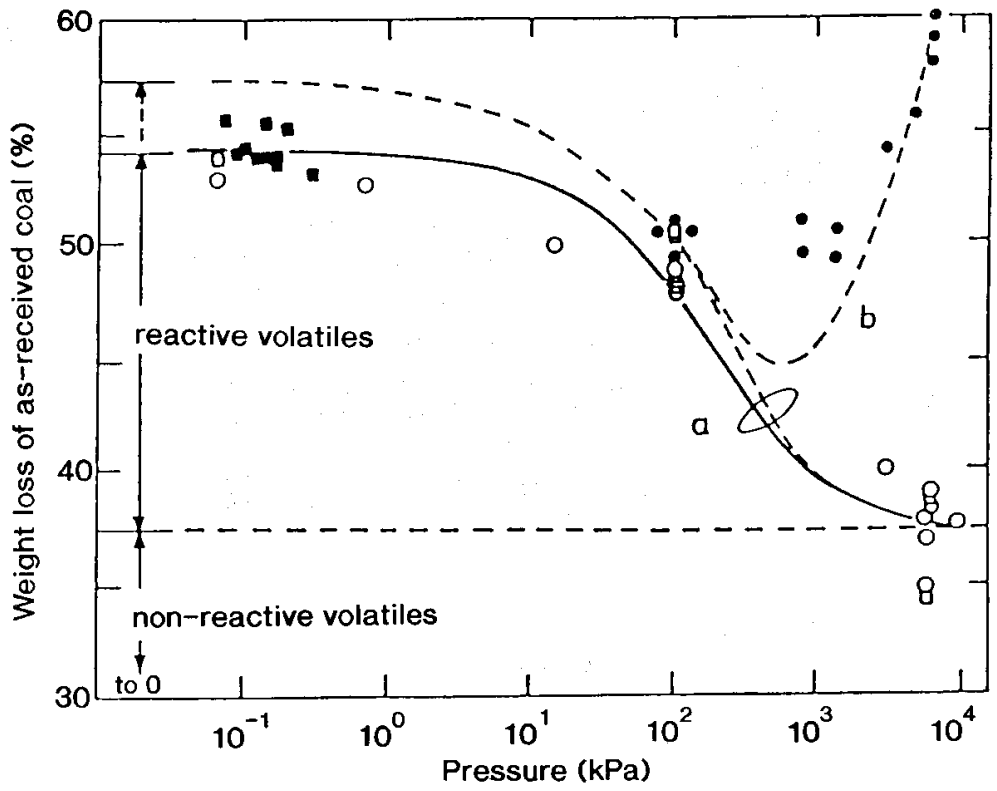

Gurves $a$ and $b$, calculated from a kinetic model.

Final temperature: $1000^{\circ} \mathrm{C}$

Residence time: 5-20 s

Heating rate: $650-10000^{\circ} \mathrm{C} / \mathrm{s}$

Fig. 8. Effect of pressure on weight loss from coal heated in $\mathrm{He}(\square, \boldsymbol{\square}, \bigcirc)$ and $\mathrm{H}_{2}(\boldsymbol{O})$ atmospheres. 
the secondary reactions. ${ }^{4)}$ On the other hand, high pressure of hydrogen is preferred to the production of volatile products.

\subsection{Secondary Reactions of Primary Volatiles in Gas Phase}

The primary volatiles diffusing out of the surface of particle would undergo the secondary reactions in gas phase. The temperature, the residence time of volatiles in heated gas phase, and the pressure of carrier gas affect such reactions to a significant extent. The two-stage pyrolysis shows that, in the case of inert carrier gas, the secondary reactions occur mainly above $600^{\circ} \mathrm{C}$, resulting in the decrease of tar and increase of gas, light hydrocarbon liquids and char (Fig. 9).25) The higher the temperature and the longer the residence time, more extensively large molecularweight compounds decompose to small ones. Table 1 shows that the structure of tar is affected by the secondary reactions. ${ }^{26}$ ) The aromaticity of tar increases as the severity of secondary reaction increases.

When hydrogen is used as carrier gas, the secondary reactions between the primary volatiles and hydrogen would increase the yields of gas, BTX and other light hydrocarbon liquids. The yields of $\mathrm{CH}_{4}$ and BTX significantly increased in the two-stage hydropyrolysis at the expense of tar (Fig. 10), when compared with the single-stage hydropyrolysis. ${ }^{27)}$

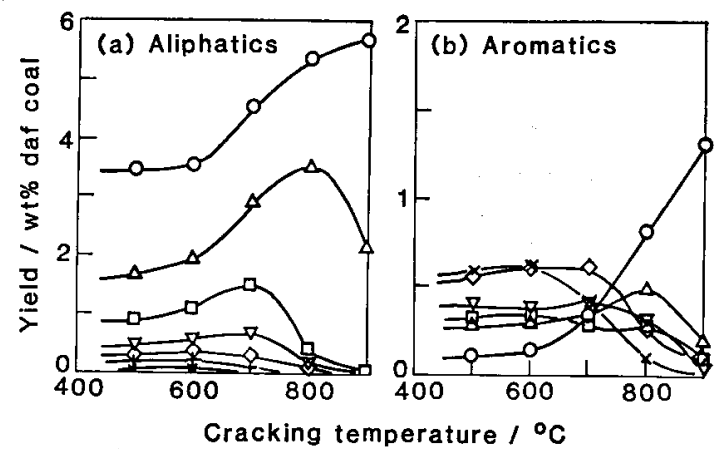

Aliphatics

$\circ: \mathrm{C}_{1}, \Delta: \mathrm{C}_{2}, \square: \mathrm{C}_{3}, \nabla: \mathrm{C}_{4}, \diamond: \mathrm{C}_{5},+: \mathrm{C}_{6}$, $x: \mathrm{C}_{7}$

Aromatics

$\mathrm{O}$ : Benzene, $\triangle$ : Toluene, $\square$ : Xylenes,

$\nabla:$ Phenol, $\diamond$ : Cresols, $x$ : Xylenols

(a) Aliphatic hydrocarbons $\left(\mathrm{C}_{1}-\mathrm{C}_{7}\right)$

(b) Aromatic hydrocarbons (BTX and PCX)

Fig. 9. Effect of temperature on the secondary reactions of volatiles from Liddell coal.

Table 1. Structural parameters of tar from Liddell coal at different pyrolysis temperatures.

\begin{tabular}{ccccccc}
\hline $\begin{array}{c}\text { Temp. } \\
\left({ }^{\circ} \mathrm{C}\right)\end{array}$ & $f_{\mathrm{a}}$ & $\alpha-C^{*}$ & $H_{\mathrm{ar}}$ & $H_{\alpha}$ & $H_{\beta}$ & $H_{\gamma}$ \\
\hline 500 & 0.60 & 0.33 & 0.21 & 0.30 & 0.41 & 0.03 \\
600 & 0.64 & 0.40 & 0.23 & 0.28 & 0.40 & 0.03 \\
693 & 0.65 & 0.60 & 0.30 & 0.36 & 0.25 & 0.02 \\
805 & 0.81 & 0.73 & 0.49 & 0.32 & 0.11 & 0.01 \\
905 & 0.88 & 0.60 & 0.68 & 0.15 & 0.11 & 0.01 \\
\hline
\end{tabular}

${ }^{*} \alpha-C: C_{\alpha} /\left(C_{\alpha}+C_{\beta}+C_{\gamma}\right)$.

\subsection{Secondary Reactions of Primary Volatiles over Solid Surfaces}

The secondary reactions of primary volatiles could be promoted by catalysts. The removal of minerals from coal increases the yield of volatile matter, ${ }^{28-30}$ ) and the inverse is also correct. ${ }^{28,31-33)}$ The ion-exchangeable metals affect the decomposition of oxygencontaining functional groups, and decrease the final yields of tar. ${ }^{28}$ ) The extent becomes large when the amount of metal increases. Although the detailed mechanism is not clear yet, the effects on both pyrolysis itself and the secondary reactions should be considered. The minerals physically mixed to coal show an obvious catalytic effect on the secondary reactions.

The catalytic effect of some metal oxides, the main components of coal ash, on the secondary reactions of fresh volatiles was investigated using a two-stage reactor. ${ }^{34)}$ The existence of alumina, silica, iron oxide and calcium oxide in the second zone of the reactor promoted the cracking of the fresh volatiles evolved in the first zone. Char produced during pyrolysis also showed a similar catalytic effect on the secondary reactions. ${ }^{35)}$ Commercial catalysts like $\mathrm{Co} / \mathrm{Mo}, \mathrm{Ni} /$ Mo and Ni/W supported on alumina strongly modified the secondary hydrocracking of fresh volatiles, producing a large amount of methane and BTX even at a low temperature range of around $500^{\circ} \mathrm{C} .{ }^{36}$ )

\section{Control of Product Yields}

As stated above, coal pyrolysis is very complex, and the reaction consist of the pyrolysis of coal molecules and the secondary reactions of primary volatiles (Fig. $\left.11^{37)}\right)$. Since various factors affect the product yields, it is necessary to carry out the pyrolysis under an optimum combination of operation conditions. In this section, the factors controlling the yields of each product will be discussed.

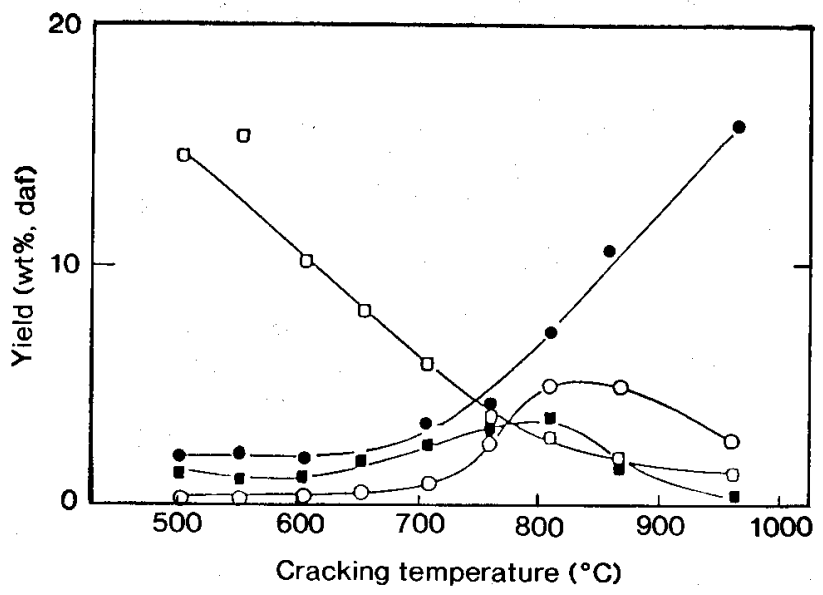

$\mathrm{H}_{2}$ pressure: $15 \mathrm{MPa}$

Vapor residence time at $827^{\circ} \mathrm{C}: 7 \mathrm{~s}$

-: $\mathrm{CH}_{4}, \quad \mathrm{O}$ : Benzene, $\mathbf{\square}$ : ethane, $\square$ : $\operatorname{tar}$

Fig. 10. Effect of cracking temperature of primary volatiles on product yields during two-stage hydropyrolysis of Linby coal. 


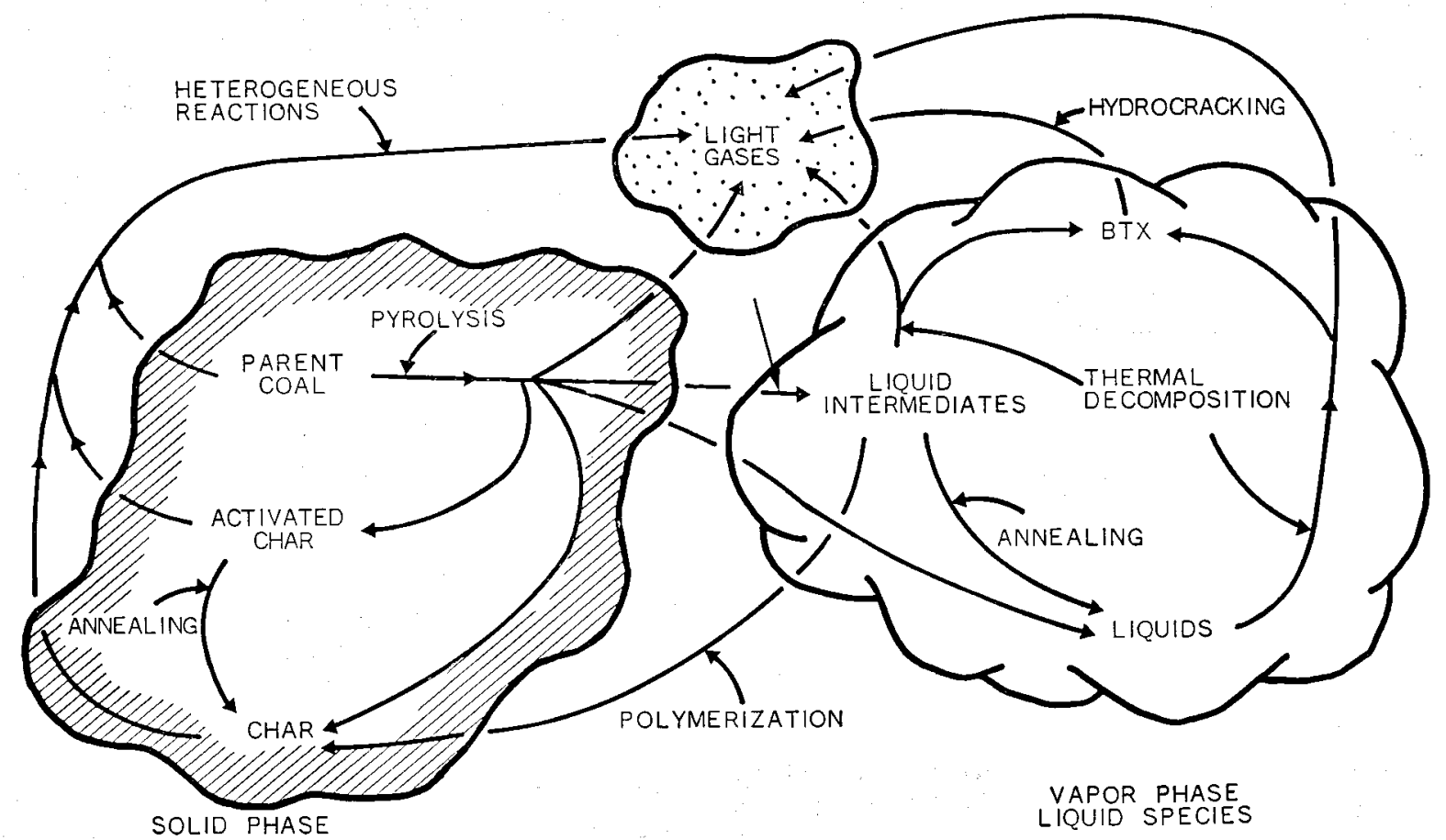

Fig. 11. Reaction pathways of flash hydropyrolysis of coal.

\subsection{Methane}

Methane is a main component of gaseous hydrocarbon evolved from coal pyrolysis. In fact, methane is a target product in the production of fuel gas, SNG, from coal pyrolysis. In general, high temperature and high hydrogen pressure accelerate the reaction of hydrogen with coal and volatiles, leading to methane production. $7,25,27)$

Catalytic hydrocracking of primary volatiles at ambient hydrogen pressure leads to the conversion of all volatiles to methane over $\mathrm{Co} / \mathrm{Mo} / \mathrm{Al}_{2} \mathrm{O}_{3}$ catalyst or Ni-loaded minerals even at low temperatures. ${ }^{36,38)}$ The extent of hydrocracking significantly depends on the operation conditions like the kind of catalysts and the hydrocracking temperature (Fig. 12). ${ }^{36)}$

\subsection{Other Hydrocarbon Gases}

In addition to methane, hydrocarbon gases also evolves from coal hydropyrolysis more or less. Ethylene can be used as an alternative chemical feedstocks which generally come from petroleum refinery. Among $\mathrm{C}_{4}$ hydrocarbons, iso-butene is important raw material for the production of methyl tetr-butyl ether. These hydrocarbon gases can also be used as fuels. The yields of these hydrocarbons are so low that they have attracted less attention than methane. Mainly saturated hydrocarbon gases evolve from hydropyrolysis, because of the hydrogenation of unsaturated compounds. It is possible to maximize the yields of these hydrocarbons by controlling the reaction conditions during the two-stage pyrolysis and the catalytic hydropyrolysis as shown in Figs. 9, 10 and 12.

\subsection{Light Hydrocarbon Liquids}

Light hydrocarbon liquids consist of aliphatic and

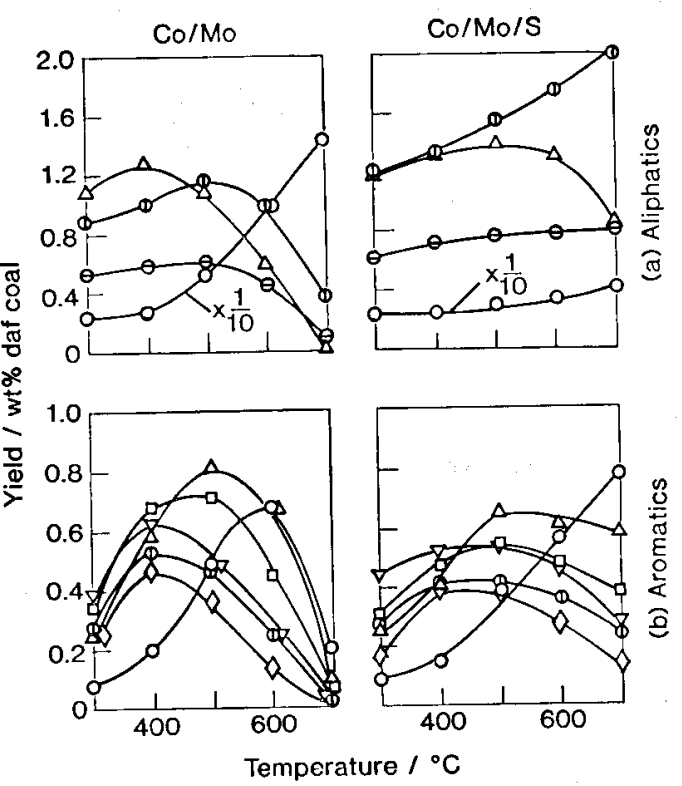

$$
\begin{aligned}
& \text { Aliphatics } \\
& \text { O: } \mathrm{C}_{1}, \Phi: \mathrm{C}_{2}, \quad: \mathrm{C}_{3}, \quad \triangle: \mathrm{C}_{4}-\mathrm{C}_{7} \\
& \text { Aromatics } \\
& \text { O: Benzene, } \triangle: \text { Toluene, } \square: \text { Xylene, } \\
& \text { ๑: Phenol, } \nabla: \text { Cresols, } \diamond: \text { Xylenols }
\end{aligned}
$$

Fig. 12. Effect of temperature during the hydrocracking of volatiles from Liddell coal over $\mathrm{Go} / \mathrm{Mo} / \mathrm{Al}_{2} \mathrm{O}_{3}$ and $\mathrm{Co} / \mathrm{Mo} / \mathrm{S} / \mathrm{Al}_{2} \mathrm{O}_{3}$ catalysts.

light aromatic hydrocarbons. The aliphatic hydrocarbons can be used directly as fuel or as chemical feedstocks, but the yields are very low. Mononuclear aromatic hydrocarbons like BTX and PCX (phenol, cresols and xylenols) can be used as chemical feedstocks, and therefore, they are important from the view point of economics. The yield of BTX directly 
relates to the economics of coal utilization.

There is an optimum temperature at which a maximum BTX yield can be achieved during hydropyrolysis of lignite (Fig. 13). At high temperature, BTX decrease due to the decomposition. The yield of $>\mathrm{C}_{9}$ oil becomes maximum near $750^{\circ} \mathrm{C}$. Thus it should be avoided to pyrolyze coal at too high temperature. On the other hand, many studies show that the yields of BTX and other light hydrocarbon liquids increased with the increase in hydrogen pressure (Fig. 4) and by the use of various inorganic catalysts. ${ }^{39)}$ The selection of coal type is also important (Fig. 5).

Two-stage hydropyrolysis might be an effective method to increase the yields of light hydrocarbon liquids. The catalytic hydrocracking of primary volatiles under suitable conditions may bring about an

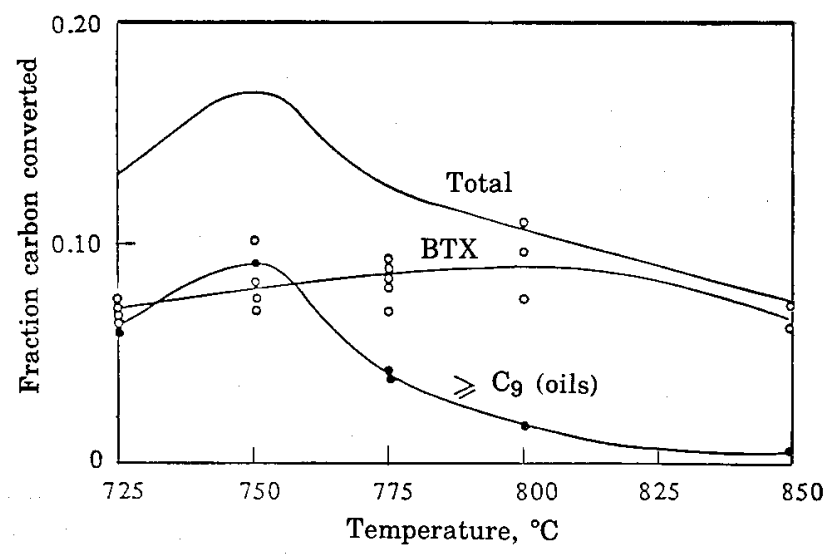

$\mathrm{H}_{2}$ pressure: $13.8 \mathrm{MPa}$

Fig. 13. Liquid yield from flash hydropyrolysis of lignite. increased yield of BTX (Fig. 12). ${ }^{36)}$

\subsection{Heavy Hydrocarbon Liquids}

One of main products from hydropyrolysis is heavy hydrocarbon liquids, called as tar in general. It contains a number of polynuclear aromatic hydrocarbons. Fig. 14 illustrates one example which shows how complicated the tar is. There are so many compounds even in benzene soluble fraction. ${ }^{40)}$

Tar can be used to make carbon materials or as fuel. When used as fuel, desulfurization and denitrogenation are necessary to reduce the environmental pollution. This seems to be economically unfeasible at present moment. Compounds separated from tar can be applied to many fields such as medical, electronics and others. The studies on converting polynuclear aromatic hydrocarbons which exist in tar to more useful aromatics have been carried out extensively, but there are many difficulties to be overcome.

As in the case of light hydrocarbon liquids, an optimum combination of operation conditions (coal type, pyrolysis temperature and catalysts) is important to obtain a high yield of heavy hydrocarbon liquids. The yield of tar is higher from bituminous coals than from lignites (Fig. 5). High hydrogen pressure is preferable.

Recently, Miura et al. ${ }^{41)}$ found that the pretreatment of coal with hydrogen-donor solvents increased the yield of tar to a great extent (Fig. 15). The extent of increase in tar yield was related to the amount of hydrogen which can be transferred from the solvent to the coal. Such a new concept may lead to a new coal utilization technology.

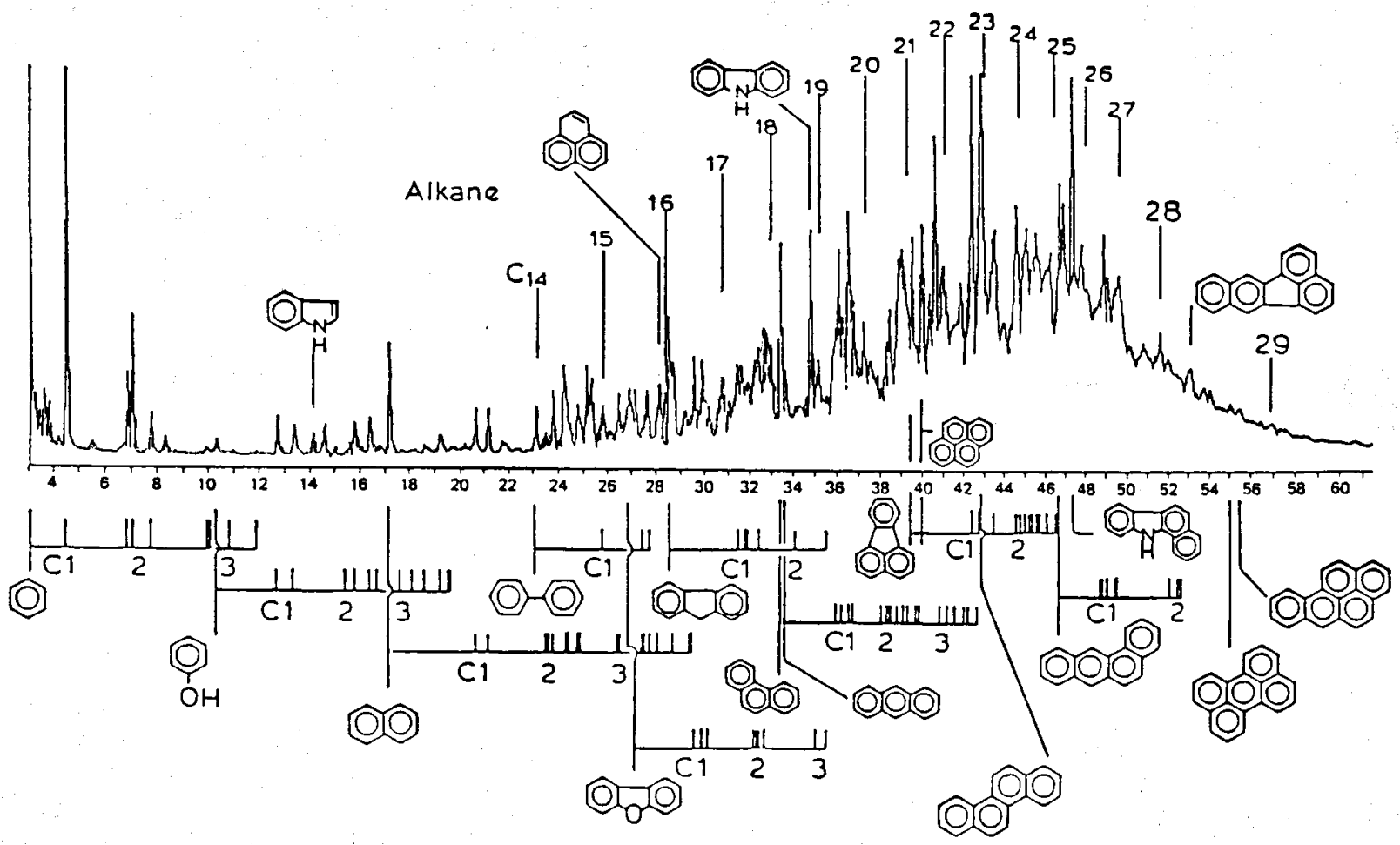

Fig. 14. Gas chromatogram of benzene-soluble fraction of tar from Devco coal. 


\subsection{Char}

It is impossible to completely convert coal to volatiles without any residues. In a hydropyrolysis process, char is usually used to make hydrogen which is necessary for the pyrolysis. An excess amount of char is undesirable although it can be used as fuel. High hydrogen pressure, high temperature and use of catalysts are expected to reduce the char yield.

\section{Typical Flash Pyrolysis Processes}

Many pyrolysis processes have been developed for different purposes, and at present some processes are under devclopment for the production of SNG and chemicals. The concept of flash hydropyrolysis process is shown in Fig. 16. The processes differ from each other in (1) the purpose, (2) the heating method, (3) the method of $\mathrm{H}_{2}$ production for the process, (4) the operation conditions, and (5) the method to avoid agglomeration problem. Table 2 summarizes the information of some typical processes developed and under development.

\subsection{Garrett Flash Pyrolysis Process}

In the process developed by Garrett Research Corporation, tar, which can be further hydrogenated to

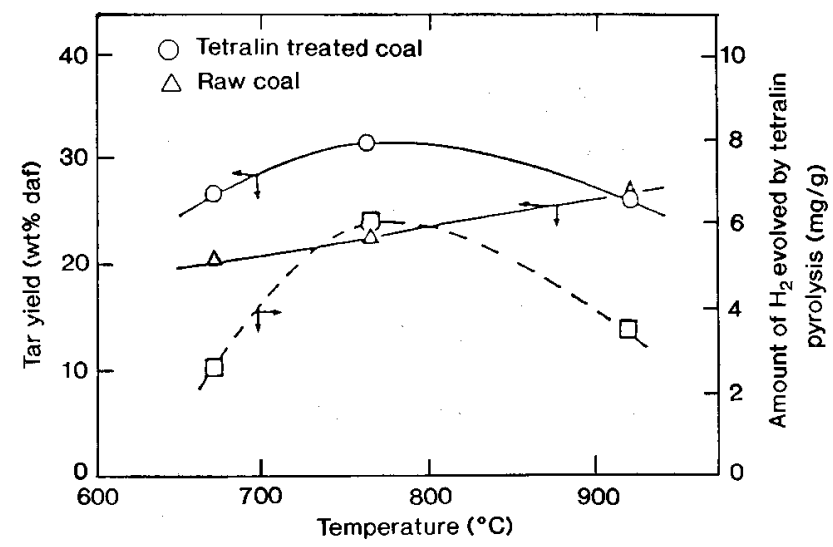

Fig. 15. Effect of tetralin treatment on tar yield from Taiheyo coal. refinable liquids, are extracted by flash pyrolysis of coal, and the resulting char and gas are used as fuels in conventional utility boilers. ${ }^{42)}$

The process used an entrained-flow reactor to pyrolyze dried and pulverized coal. Char heated to $650-870^{\circ} \mathrm{C}$ by partial combustion of char itself provides the heat to the mixture of coal and $\mathrm{H}_{2}$. Product vapors are cooled by recycle oil. The reactor is designed to operate at $0.17 \mathrm{MPa}$ and with a particle heat-up time of about $0.1 \mathrm{~s}$. The process yields liquid 1.5-2.0 times greater than normal Fischer assay. At reaction temperature above $600^{\circ} \mathrm{C}$, gas yield increased at the expense of liquids due to the extensive cracking of primary liquid vapors. Approximately $50 \%$ of coal remained as char.

The high solid circulation rate and large equipment size result in relatively high capital and opcrating cost. Tar cracking occurs on the surface of the recycle char used as heat transfer agent. For optimization of liquid yields, new heat carrier has to be considered.

\subsection{Cities Service Hydropyrolysis Process}

Short residence time hydropyrolysis process (CSSR process) was developed by Cities Service R \& D Co. to produce liquids. ${ }^{42}$ ) In the bench-scale unit, pulverized dry coal is fed into the reactor through a proprietary nozzle, and heated by hot $\mathrm{H}_{2}$ at a heating rate of $30000-80000^{\circ} \mathrm{C} / \mathrm{s}$. The products then are quenched by cryogenically cooled $\mathrm{H}_{2}$ in the cooler. A lignite and a western Kentucky bituminous ccal have been tested. The overall carbon conversion increases with reaction temperature $\left(670-860^{\circ} \mathrm{C}\right)$ to an asymptote at about $46 \% ; \mathrm{H}_{2}$ consumption at this level is $6.8 \mathrm{wt} \%$ (daf) of coal. Carbon selectivity to liquid is maximum at $43 \%$ conversion level while at a higher conversion the product is mostly methane. A short particle residence time is necessary to produce the liquids like BTX. The yield of light aromatic oil (essentially benzenes) is $12-16 \mathrm{wt} \%$ (daf). Representative results with North Dakota lignite are shown in Table 3.

Two conceptual plans were proposed for the $\mathrm{H}_{2}$

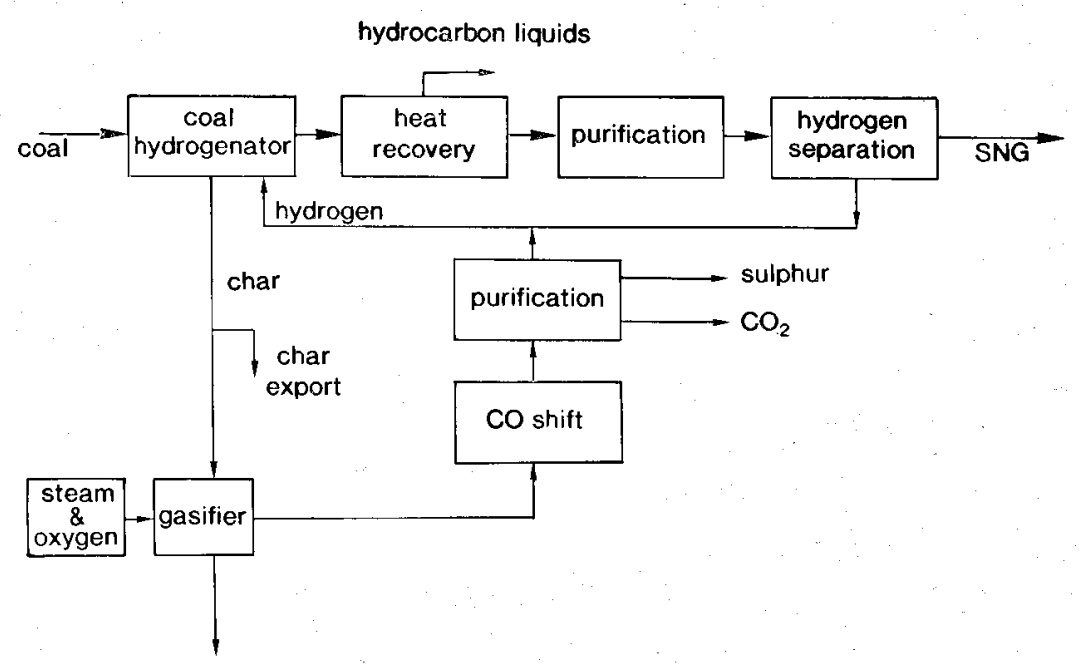

slag or ash
Fig. 16.

Block diagram of coal hydropyrolysis process for $\mathrm{SNG}$ production. 


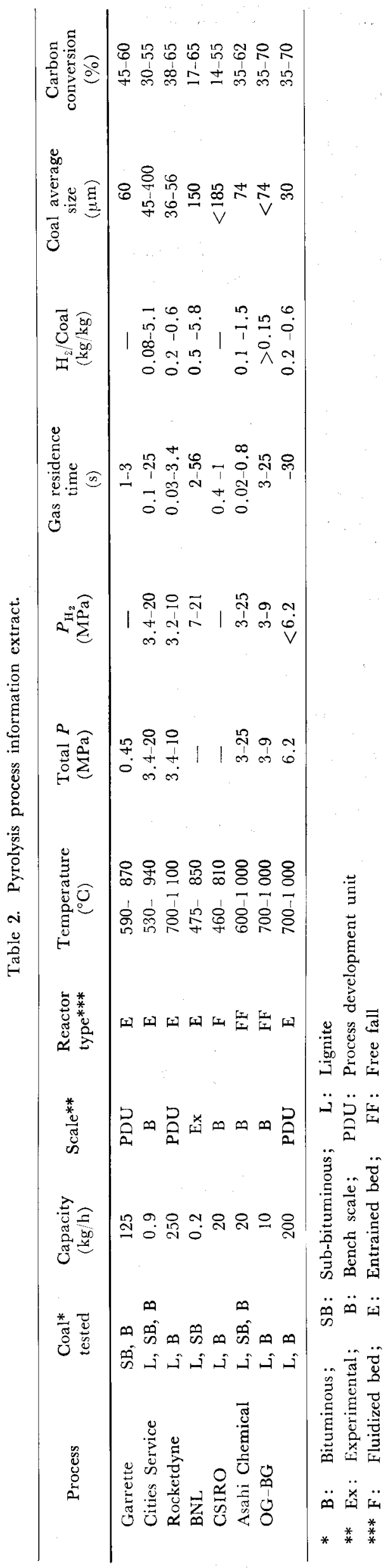

Table 3. Results of Cities Service hydropyrolysis process. (North Dakoda lignite)

$\begin{array}{lc}\mathrm{H}_{2} / \mathrm{Coal} \text { ratio }(\mathrm{kg} / \mathrm{kg}) & 0.18-2.0 \\ \text { Reactor temperature }\left({ }^{\circ} \mathrm{C}\right) & 621-857 \\ \text { Reactor pressure }(\mathrm{MPa}) & 3.4-20.6 \\ \text { Particle residence time }(\mathrm{s}) & 0.1-3 \\ \text { Yield: Gas }\left(\mathrm{m}^{3}(\mathrm{STP}) / \mathrm{t}\right) & 547 \\ \quad \text { Liquids }(l / \mathrm{t}) & 100\end{array}$

supply to the process; the steam reforming of part of product gas $\left(\mathrm{CH}_{4}\right)$ with char being gasified with air to provide fuel gas for the reformer and for electricity; or gasification of coal and char with steam and oxygen.

\subsection{Rocketdyne Flash Hydropyrolysis Process}

This process, featuring rapid hydropyrolysis of coal in a dense phase, has been developed by Rockwell International Corporation. ${ }^{44,45)}$ Investigations were conducted in a $1 \mathrm{t} / \mathrm{h}$ reactor with a hydrogen preheater and an oxygen-hydrogen combustor that supplies heat to the process. Pulverized coal and hot hydrogen are fed downward to the reactor injector. Coal and $\mathrm{H}_{2}$ are allowed to react for 20-200 ms at $800-1000^{\circ} \mathrm{C}$, before being quenched by water spray and heat exchange. Western Kentucky, Illinois and Montana coals were successfully tested. About 30$40 \%$ of the carbon in the coal was converted to liquid products. The total carbon conversion increased with temperature and residence time, ranging from 30 to $60 \%$.

The process uses the combustion heat of pure $\mathrm{O}_{2}$ and $\mathrm{H}_{2}$, and thus produced a large amount of water which increases a load for the waste water treatment. Tokyo Gas Company recently starts a new pyrolysis project by using a similar technology.

\subsection{BNL Flash Pyrolysis Process}

From 1975, Brookhaven National Laboratory $(B N L)^{46)}$ has operated a $0.9 \mathrm{~kg} / \mathrm{h}$ bench scale unit with a $2 \mathrm{~cm}$ dia. $\times 2.4 \mathrm{~m}$ long dilute phase reactor to evaluate the process which was originally developed in the US Bureau of Mines in early 60's. Pulverized coal and hot recycled $\mathrm{H}_{2}\left(980^{\circ} \mathrm{C}\right)$ are mixed and fed to the entrained downflow tubular reactor. $\mathrm{H}_{2}$ is produced partly from char gasification and partly from cracking of hydrocarbon vapors produced.

Experimental conditions to obtain the maximum liquid yield from North Dakota lignite are: pressure, $14 \mathrm{MPa}$; temperature, $775^{\circ} \mathrm{C}$; residence time, $7 \mathrm{~s} ; \mathrm{H}_{2} /$ coal, $0.84 \mathrm{~kg} / \mathrm{kg}$. Under these conditions, the carbon conversion to total liquid was $20 \%$, and BTX yield was $10 \%$. Increase in residence time over $20 \mathrm{~s}$ reduces the overall carbon conversion, lowering the yield of liquids but increasing the gas yield. The problem is the plugging of the reactor with caking coals.

The pyrolysis of coal in $\mathrm{CH}_{4}$, the main component of natural gas, has also been tried in this laboratory, and some increase of $\mathrm{C}_{2} \mathrm{H}_{4}$ and benzene was observed. ${ }^{47)}$ Recently, the HYDROGARB process ${ }^{88}$ has 
been developed for the production of clean carbon particulate fuel. This process consists of deep hydrogenation of coal for the production of $\mathrm{CH}_{4} \cdot \mathrm{CH}_{4}$ is subsequently thermally cracked to fine carbon black particulates and $\mathrm{H}_{2}$ gas. The excess $\mathrm{H}_{2}$ is recycled. The clean particulate carbon is mixed with water or methanol to produce slurry fuels.

\subsection{CSIRO Pyrolysis Process}

A continuous fluidized bed process is designed to produce liquid fuels in the Commonwealth Scientific and Industrial Research Organization (CSIRO), Australia. ${ }^{49,50)}$ A bench unit of $20 \mathrm{~kg} / \mathrm{h}$ was operated using Australian lignite, sub-bituminous and bituminous coals. The maximum yields of tar for Loy Yang, Millmerran and Liddell coals were 23, 35 and $31 \mathrm{wt} \%(\mathrm{dal})$ at pyrolysis temperature of $580-600^{\circ} \mathrm{C}$, respectively. Tars from sub-bituminous and bituminous coals were successfully converted to refineryfeedstock grade oils in catalytic hydrogenator.

The main drawbacks for fluidized bed reactor are the agglomeration of coal in the bed and a restriction on the coal size. To prevent the agglomeration of coal, part of char is blended continuously back with the incoming coal. As a whole, they concluded the cost of oil by flash pyrolysis is too high at the present moment.

\subsection{Asahi Chemical Industry Process}

Flash hydropyrolysis process has been developed in Asahi Chemical Industries Co. Ltd., Japan, using a fluidized bed for the purpose of the production of liquid fuel. ${ }^{39)}$ In the non-catalytic hydropyrolysis process, coal is flash pyrolyzed at temperature of $800-$ $1000^{\circ} \mathrm{C}$ at a heating rate of $10^{4^{\circ}} \mathrm{C} / \mathrm{s}$, with the $\mathrm{H}_{2}$ pressure of 3-25 $\mathrm{MPa}$, the residence time of 20-800 $\mathrm{ms}$ and the hydrogen $/$ coal ratio of $0.1-1.5 \mathrm{~kg} / \mathrm{kg}$. The volatiles evolved are further hydrocracked at temperature of $570-850^{\circ} \mathrm{C}$ with a vapor residence time of $1-6 \mathrm{~s}$. The tests with Illinois No. 6 coal showed that the two-stage pyrolysis produces more ethane and gasoline components than one-stage pyrolysis does. The effect of various inorganic salts has also been investigated (Table 4). The addition of $\mathrm{Fe}, \mathrm{Co}$, and $\mathrm{Ni}$ compounds increased the overall carbon conversion by $20-30 \%$. The increases in the yields of methane, ethane and liquids are also obvious.

\section{7. $O G \& B G$ Hydropyrolysis Process}

In 1986 Osaka Gas Co. (OG) and British Gas PLC (BG) began a research program to develop an efficient process which can use whole fine coa! to produce SNG which is compatible with imported natural gas and to obtain valuable hydrocarbon liquid as co-products. ${ }^{51)}$

A free fall type bench unit allows testing of coals at a rate up to $10 \mathrm{~kg} / \mathrm{h}$. The tests were carried out under the following conditions; temperature, 700$1000^{\circ} \mathrm{C}$; pressure, 3-9 $\mathrm{MPa}$; residence time, 3-25 s; and hydrogen/coal ratio, more than $0.15 \mathrm{~kg} / \mathrm{kg}$. Typical results are shown in Fig. 17. It is necessary to operate at medium temperature $\left(800^{\circ} \mathrm{C}\right)$ to obtain a maximum yield of BTX. The overall carbon conversion at $800^{\circ} \mathrm{C}$ was $55 \%$, while it reached $70 \%$ at $1000^{\circ} \mathrm{C}$.

At Midlands Research Station of British Gas PLC, an entrained-flow coal hydropyrolysis reactor with a size of $5 \mathrm{t} / \mathrm{d}$ (Fig. 18) is developed to confirm the above results in a large scale. The heat exchange between the hot products and the incoming reactants was designed with internal circulation system. Tests have been carried out at pressure of $6.2 \mathrm{MPa}$, tem-

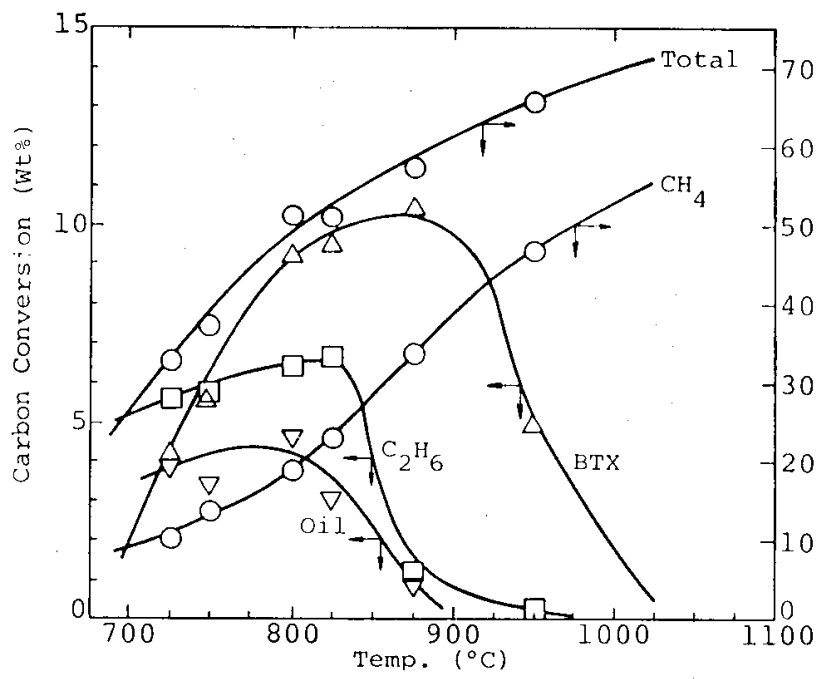

Fig. 17. Relationship between carbon conversion and pyrolysis temperature in OG \& BG bench test.

Table 4. Product yield* in catalytic hydropyrolysis of an Australian lignite (C\%(daf), 65.1) at $7 \mathrm{MPa}_{2}$

\begin{tabular}{|c|c|c|c|c|c|c|c|c|c|}
\hline \multirow{2}{*}{ Metal** } & \multirow{2}{*}{\multicolumn{2}{|c|}{ None }} & \multicolumn{3}{|c|}{$\mathrm{Fe}$} & \multicolumn{2}{|c|}{$\mathrm{Ni}$} & \multicolumn{2}{|c|}{ Co } \\
\hline & & & $O$ & $H$ & $S$ & $H$ & $\mathcal{N}$ & $O$ & $C$ \\
\hline$T\left({ }^{\circ} \mathrm{C}\right)$ & 795 & 670 & 700 & 680 & 740 & 660 & 760 & 690 & 670 \\
\hline $\mathrm{CH}_{4}$ & 26 & 18 & 24 & 22 & 25 & 21 & 25 & 23 & 23 \\
\hline $\mathrm{C}_{2}$ & 4 & 5 & 10 & 12 & 6 & 14 & 5 & 10 & 9 \\
\hline $\mathrm{CO}+\mathrm{CO}_{2}$ & 8 & 6 & 7 & 7 & 7 & 7 & 7 & 7 & 7 \\
\hline Gasoline & 7 & 3 & 12 & 15 & 13 & 16 & 11 & 13 & 12 \\
\hline Oil & 5 & 8 & 13 & 15 & 12 & 14 & 11 & 11 & 14 \\
\hline Char & 52 & 60 & 34 & 29 & 37 & 28 & 41 & 35 & 35 \\
\hline
\end{tabular}

* Carbon conversion (\%)

** $O$ : Oxide; $H:$ Hydroxide; $S:$ Sulfate; $\mathcal{N}:$ Nitrate; $C:$ Carbonate 


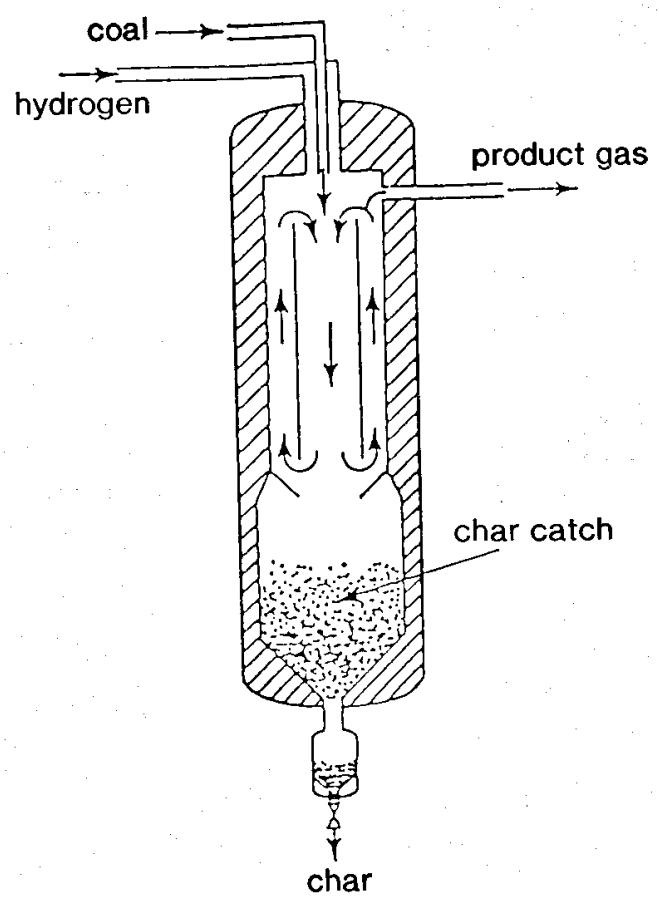

Fig. 18. Coal hydrogenator designed by British Gas PLC.

Table 5. Typical results from OG-BG pilot plant.

\begin{tabular}{lcc}
\hline \multicolumn{1}{c}{ Coal type } & $\begin{array}{c}\text { Manvers } \\
\text { bituminous } \\
\text { coal }\end{array}$ & $\begin{array}{c}\text { Loy Yang } \\
\text { lignite }\end{array}$ \\
\hline Pressure $(\mathrm{MPa})$ & 6.2 & 6.2 \\
Temperature $\left({ }^{\circ} \mathrm{C}\right)$ & 956 & 875 \\
$\mathrm{H}_{2} /$ Coal ratio $(\mathrm{kg} / \mathrm{kg}(\mathrm{daf}))$ & 0.3 & 0.4 \\
Coal feed rate $(\mathrm{kg} / \mathrm{h})$ & 66 & 89 \\
Gas residence time $(\mathrm{s})$ & 30 & 10 \\
Carbon conversion $(\%)$ & & \\
Methane & 42 & 33 \\
Other gases & 3 & 12 \\
Benzene & 1 & 7 \\
Heavy liquids & - & 2 \\
Total & 46 & 56 \\
\hline
\end{tabular}

peratures up to $1000^{\circ} \mathrm{C}$ and hydrogen/coal ratios in the range of $0.17-0.6 \mathrm{~kg} / \mathrm{kg}$. Typical results are shown in Table 5 . It is claimed that an energy balance shows a high thermal efficiency of $77.8 \%$ and a cost analysis shows a lower capital cost than competing technologies.

\section{Conclusion}

As stated above, many processes have been developed for the production of SNG, liquid fuels, or chemical feedstocks. It is economically difficult to develop a process with the production of only liquid fuels or SNG without chemicals. The efforts at present should be made on increasing the overall carbon conversion and the production of maximum amount of chemicals like BTX. In order to reach this purpose, it is necessary to optimize the operating conditions. Developments of new pyrolysis concepts like catalytic pyrolysis or co-processing with other resources would be effective to make a break-through on this process.

\section{REFERENCES}

1) D. B. Anthony and J. B. Howard: AIChE J., 22 (1976), 625.

2) J. B. Howard: Chemistry of Coal Utilization, Second Suppl. Vol., M. A. Elliott, ed., John Wiley \& Sons, New York, (1981), 665.

3) G. R. Gavalas: Coal Pyrolysis, Elsevier, Amsterdam, (1982).

4) S. Furfari: "Hydropyrolysis of Coal", Rep. No. ICTIS/ TR20, IEA Coal Research, London, (1982).

5) P. R. Solomon and D. G. Hamblen: Chemistry of Coal Conversion, R. H. Schlosberg, ed., Plenum Press, New York, (1985), 121.

6) J.H. Shinn: Fuel, 63 (1984), 1187.

7) H. Jüntgen: Fuel, 63 (1984), 731.

8) M.S. Seehra, B. Ghosh and S. E. Mullins: Fuel, 65 (1986), 1315.

9) P. R. Solomon and H.-H. King: Fuel, 63 (1984), 1302.

10) K. R. Squire, P. R. Solomon, R. M. Carangelo and M. B. Di'Taranto: Fuel, 65 (1986), 833.

11) M. D. Ettinger, S. R. Mahasay and L. M. Stock: Energy Fuels, 1 (1987), 274.

12) G. R. Rose, R. F. Zabransky and L. M. Stock: Fuel, 63 (1984), 1339.

13) W.-C. Xu and A. Tomita: Fuel, 66 (1987), 627.

14) W. H. Calkins, E. Hagaman and H. Zeldes: Fiuel, 63 (1984), 1113.

W. H. Calkins and R. J. Tyler: Fuel, 63 (1984), 1119.

W. H. Calkins: Fuel, 63 (1984), 1125.

15) W.-C. Xu: Ph.D. thesis, Tohoku University, (1989), 36.

16) A. F. Gaines and Y. Yurum: Fuel, 55 (1976), 129.

17) A. Sulimma, P. Leohhardt, K. H. van Heek and H. Jüntgen: Fuel, 65 (1986), 1457.

18) K. Ouchi and H. Honda: J. Fuel Soc. Jpn., 40 (1961), 845.

19) E. M. Suuberg, W. A. Peters and J. B. Howard: Fuel, 59 (1980), 405.

20) R. J. Tyler: Fuel, 59 (1980), 218.

21) W.-G. Xu and A. Tomita: Fuel, 66 (1987), 632.

22) D. B. Anthony, J. B. Howard, H. C. Hottell and H. P. Meissner: Fuel, 55 (1976), 121.

23) C. Roy, B. de Caumia, and W. Kalkreuth: Fuel, 64 (1985), 1662.

24) G. H. Ko, W. A. Peters and J. B. Howard: Fuel, 66 (1987), 1118.

25) W.-G. Xu and A. Tomita: Fuel Process. Technol., 21 (1989), 25.

26) P. J. Collin, R. J. Tyler and M. A. Wilson: Fuel, 59 (1980), 479.

27) M.J. Finn, G. Fynes, W. R. Ladner and J.O.H. Newman: Fuel, 59 (1980), 397.

28) R. J. Tyler and H.N.S. Schafer: Fuel, 59 (1980), 487.

29) M. E. Morgan and R. G. Jenkins: Fuel, 65 (1986), 764.

30) H. D. Franklin, R. G. Cosway, W. A. Peters and J. B. Howard: Ind. Eng. Chem. Process Des. Deu, 22 (1983), 39.

31) H. D. Franklin, W. A. Peters and J. B. Howard: Fuel, 61 (1982), 155.

32) Y. D. Yeboah, J. P. Longwell, J. B. Howard and W. A. Peters: Ind. Eng. Chem. Process Des. Dev., 19 (1980), 646.

33) H. D. Franklin, W. A. Peters, F. Cariello and J. B. Howard: Ind. Eng. Chem. Process Des. Dev, 20 (1981), 670.

34) M. A. Serio, W. A. Peters, K. Sawada and J. B. Howard: Proc. Int. Conf. on Coal Sci., Pittsburgh, (1983), 533-536.

35) W.-G. Xu and A. Tomita: Fuel, 68 (1989), 673.

36) W.-C. Xu and A. Tomita: Proc. of 1989 Int. Conf. Coal Sci., Vol. 1, (1989), 635.

37) L. P. Combs, D. Heister, M. D. Schuman, N. J. Patel, M. P. Garey and W. L. Lee: "Coal Gasification Process Development", Third Annual Technical Progress, Rep. ET- 
10328-36, (1981).

38) K. Fuda, M. Kimura, N. Miyamoto and T. Matsunaga: $J$ Fuel Soc. Jpn., 66 (1987), 427.

39) M. Kimura and S. Kai: Japan Patent (Kokai Tokkyo Koho A) Sho-59-20382, (1984).

40) K. C. Teo and A. P. Watkinson: Fuel, 66 (1987), 1123.

41) K. Miura, K. Mae, T. Yoshimura and K. Hashimoto: Prepr. Ann. Meeting on Coal Science, Japan., Sapporo, (1989), 260.

42) S. K. Chakrabartty and M. P. du Plessis: Modern Coal Pyrolysis, Alberta Research Council, (1982).

43) M. I. Greene: Fuel Process. Technol., 1 (1977), 169. C. J. Ladelfa and M. I. Greene: Fuel Process. Technol., 1 (1977), 187.

44) C. L. Oberg, A. Y. Falk and J. Silverman: Coal Process. Technol., 5 (1979), 182.

45) C. L. Oberg and A. Y. Falk: Coal Process. Technol., 6
(1980), 159.

46) M. Steinberg and P. Fallon: Chem. Eng. Prog., 75 (1979), No. 6, 63 .

47) M. S. Sundaram, M. Steinberg and P. Fallon: Prepr. ACS Div. Fuel Chem., 29 (1984), No. 2, 129.

48) M. Steinberg: Proc. of 1987 Int. Conf. on Coal Sci., ed. by Moulijn et al., Elsevier, Amsterdam, (1987), 953.

59) J. H. Edwards, I. W. Smith and R. J. Tyler: Fuel, 59 (1980), 674, 681 .

50) I. W. Smith, J. H. Edwards, A. E. Firek, C.A.J. Paulson, K. Schluter and R.J. Tyler: "Oil from coal by flash pyrolysis-End of Grant Report ", NERDPP EG86/522, (1986).

51) H.J.F. Stroud and F. Noguchi: 55th Autumn Meeting of Inst. Gas Engineers, Nov. 1989, Inst. Gas Eng. Comm., (1989), 1404. 